\section{Prof. Otto Toeplitz}

Prof. Otro Toepuitz, who died on March 15 in Jerusalem, was one of that rare type of scholars who combine with a high standard of specialized research a deep interest in the history of their science and its bearing on general questions. Toeplitz, born at Breslau in 1881, studied mathematics in Breslau and Berlin, became Privatdozent at Göttingen in 1907, professor of mathematies at Kiel in 1920 and at Bonn in 1928. In 1935 he was dismissed in consequence of the racial laws of the Nazi Government and went in 1939 to Palestine as scientific adviser to the administration of the Hebrew University.

Toeplitz's mathematical interest was wide and covered all branches of research, but was deeply rooted in algebra. He liked to consider analysis as an algebra of an infinite number of variables, an example of which was given by Hilbert's treat. ment of integral equations as special cases of linear equations and quadratic forms of infinite sets of variables. Most of his papers deal with problems of this type-infinite matrices and the corresponding bilinear and quadratic forms. His great knowledge and thorough insight in this subject is testified by the article on integral equations in the "Mathematical Encyclopædia" (1928) written in collaboration with E. Hellinger. But Toeplitz's general attitude to mathematics, which he preferred to consider more as an art than as a science, is more clearly visible in his quasi-popular book "Von Zahlen und Figuren", written with Rademacher in 1930, which seems to me a masterpiece of that class of scientific literature which attempts to instruct a wider public in the fundamental ideas of science. It is not easy, but certainly fascinating reading.

In later years Toeplitz's interest went more and more to the history of mathematics. He was a classical scholar able to read Greek texts and he knew his Plato just as well as his Gauss and Weierstrass. Together with Neugebauer and Stenzel, he founded the periodical Quellen und Studien zur Geschichte der Mathematik, Astronomie und Physik, to which he contributed several articles, chiefly concerned with mathematical ideas in Plato's work.

Toeplitz had no intimate relation to physies, but had nevertheless some indirect influence in its development, the present writer being the link. As a student in Breslau, I was much under the influence of Toeplitz, who was my senior by one year, and though my interest in algebra was not great he insisted on my learning matrix calculus properly and occasionally refreshed my knowledge when we were together again as young teachers in Göttingen. This turned out to be a great advantage to me, first in developing Minkowski's form of relativity, then for the study of vibrations in crystals, which are determined, indeed, by a quadratic form of a (practically) infinite number of variables, but decidedly at the birth of quantum mechanics. When Heisenberg expressed the relations between the quantized amplitudes of atomic vibrations as a kind of symbolic product, the recollection of Toeplitz's instructions enabled me to rocognize them as matrix products and (with Jordan) to work out the principal features of quantum mechanies. Though this is only a purely formal step beyond Heisenberg's idea it is perhaps not quite trivial, as shown by the fact that Dirac, in independently developing Heisenberg's idea, invented a new formalism, his $q$-number calculus, without immediately recognizing the identity of Heisenberg's process with matrix products. Toeplitz himself regarded this unexpected application of his beloved matrices with some suspicion, and rightly from the point of view of the conscientious rigorous mathematician. But he nevertheless continued to give me his advice on special questions.

Toeplitz was devoted to teaching and spent much time and work on it. He was a faithful friend, a man of extreme kindness, but also of strong character and courage. This he amply proved during the hard years of Nazi rule, when he worked with all his force on the problem of saving young non-Aryans from Nazi persecution.

M. BoRn.

\section{Prof. Alexandre Besredka}

The recent death of Prof. A. Besredka at the age of seventy deprives France of yet another member of that sadly diminished group of scientific workers whose names are associated with the brilliant and provocative work produced in the early days of the Pasteur Institute. The mention of Besredka's name immediately evokes the whole conception of local as opposed to general or humoral immunity; a conception which has given rise to considerable controversy and thus provoked much fruitful experimental work on the nature of inflammation and the reaction of the body to infection. No memoir would, however, be complete which failed to pay tribute to Besredka's pioneer work in many fields of bacteriology and immunology. During his early days in Paris he was assistant to Metchnikoff. He applied the methods of this master to an illuminating study of the reaction of phagocytes to bacterial exotoxins and endotoxins and to the injection of mineral poisons. Later, Besredka made important contributions to the development of specific immunization against infection, notably in his studies on streptolysin and the use of sensitized vaccines. Anaphylactic shock, which is an abnormal and sometimes disastrous immune response to the injection of foreign protein, also claimed Besredka's attention.

The later years of Besredka's life were devoted to the study of local immunity to infection. He believed that immunity depends upon a state of resistance residing locally in those tissues that are attacked by an infection, and denied the importance of the general immune response of the body and the antibodies circulating in the blood stream. According to Besredka, all attempts at immunization should be applied locally to the susceptible tissue and should aim at modifying the reaction to the noxious agent. His experimental work was mainly confined to infections of the skin, such as anthrax and the staphylococcus, and to intestinal infections, such as typhoid and dysentery. In order to obtain immunity 
to skin infections Besredka advocated intracutaneous vaccination, inunction or the application of poultices containing the products of bacterial metabolism. It is true that the local resistance of the skin can be raised by these measures, but there is considerable evidence that a similar result can be obtained by non-specific stimulation and that, apart from any question of a general immune responsa to these procedures, the increased resistance to infection may be due to a non-specific inflammatory response.

In order to combat intestinal infections Besredka advocated the oral administration of bacterial vaccines combined with bile to increase the permeability of the intestinal mucosa. These vaccines have been extensively used in France; but it is difficult to express any final verdict on their efficacy, or to disentangle the local protective effect from the part played by the serum-antibodies which are undoubtedly produced.
If the contribution of a man of science can be measured not only by those discoveries or 'lucky shots' which command universal and immediate acceptance, but also by the skilful presentation of ideas which lead to original experimental work and to the exploration of fresh avenues of approach to intricate problems, then Besredka should be assured of an eminent place in the calendar of bacterio. logists.

We regret to announce the following deaths:

Prof. Heinrich Bonhoff, formerly professor of hygiene in the University of Marburg, aged seventy - six

Prof. G. Gallerani, emeritus professor of physiology in the University of Carnerino, aged seventy-six.

Prof. V. I. Sihvonen, professor of chemistry in the University of Helsinki, killed in an air raid on November 30 .

\section{NEWS AND VIEWS}

\section{Education in the Royal Air Force}

IN Nature of April 6, p. 526, we discussed at some length the urgent case for the provision of adequate educational services by the departments responsible for the Armed Forces. This discussion was mainly in terms of Army organization. The War Office, however, was not alone in showing a lack of regard for educational matters. The general education scheme of the Air Force, which had been carefully built up over many years, seems to have been virtually scrapped overnight on the outbreak of the War-the educational staff dispersed and the premises appropriated to other purposes. Even in the R.A.F. schools of technical training, of which the educational branch has been an essential component, there appears to have been a noticeable educational set-back. This is surely evidence of a regrettable failure to give educational values their proper place in a modern fighting service, manned (as the Air Force conspicuously is) by the finest types of young men the nation possesses. In the treatment meted out by the Air Ministry to its educational staff-the great majority of whom are officers with considerable scientific or technical qualificationsthere is further indication of an unfortunate attitude towards education. The civilian status which these educational officers have hitherto had has always made their task an extremely onerous one. For, disregarding the experience of the Navy and the Army-the officers of the education branches of which are commissioned officers on the same footing as executive officers, medical officers and so on-the Air Ministry has continued to impose a civilian status on its educational staff.

Nevertheless, we understand that, before the outbreak of the War, it was accepted by the Air Ministry that whilst this arrangement might be adhered to in peace, it could not work under 'active service' con- ditions. The education officers were invited to accept commissions in the Royal Air Force Volunteer Reserve, under definite conditions as to pay, rank, promotion, etc. In accordance with this scheme, all educational posts to be retained on the outbreak of war were ranked and education officers were earmarked to fill them. Uniform allowances were granted and all other necessary arrangements were made to enable the scheme to work as smoothly as possible if and when hostilities should begin. In this way, at the beginning of last September, the Air Force education officers assumed their new status. Without warning, however, education officers were informed a few months later that they had been demobilized and must revert to civilian status. That the Air Ministry now realizes something of the invidious position in which this decision has placed its education officers may be inferred from an instruction recently issued that the education officers are to wear uniform as Air Force officers notwithstanding that they have been demobilized and are no longer technically on 'active service'.

The Air Council should see to it that this state of affairs is put right without delay. The reason given for demobilizing the education officers was, we believe, that some (but by no means all) of them were receiving emoluments as Air Force officers greater than those they had received as civilians before the War-though the extent to which this would happen must surely have been known to the Air Ministry when the conditions of the scheme were drawn up. In any event, on any reasonable basis of computation, the sum involved is a mere trifle. Probably it could be eliminated entirely by an adjustment of ranks (and perhaps by other means) acceptable to the education officers, without prejudicing the Air Force status of these officers as has been done by the ill-advised steps recently taken. 